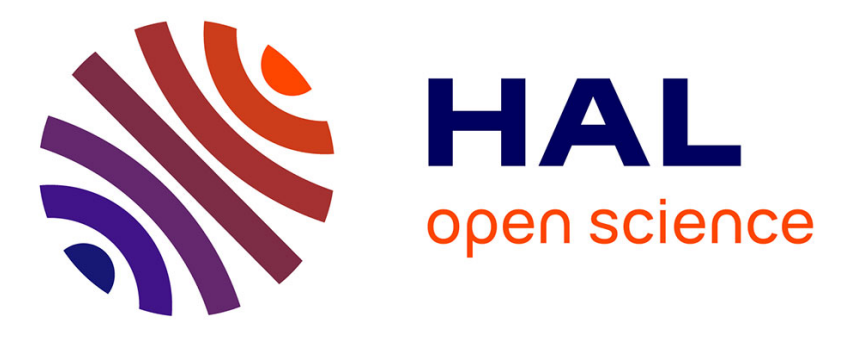

\title{
G-Quadruplex binding optimization by gold( iii ) insertion into the center of a porphyrin
}

Angélique Pipier, Aurore de Rache, Coralie Modeste, Samir Amrane, Emmanuelle Mothes-Martin, Jean-Luc Stigliani, Patrick Calsou, Jean-Louis Mergny, Geneviève Pratviel, Dennis Gomez

\section{To cite this version:}

Angélique Pipier, Aurore de Rache, Coralie Modeste, Samir Amrane, Emmanuelle Mothes-Martin, et al.. G-Quadruplex binding optimization by gold( iii ) insertion into the center of a porphyrin. Dalton Transactions, 2019, 48 (18), pp.6091-6099. 10.1039/C8DT04703K . hal-02140554

\section{HAL Id: hal-02140554 https://hal.science/hal-02140554}

Submitted on 20 Nov 2020

HAL is a multi-disciplinary open access archive for the deposit and dissemination of scientific research documents, whether they are published or not. The documents may come from teaching and research institutions in France or abroad, or from public or private research centers.
L'archive ouverte pluridisciplinaire HAL, est destinée au dépôt et à la diffusion de documents scientifiques de niveau recherche, publiés ou non, émanant des établissements d'enseignement et de recherche français ou étrangers, des laboratoires publics ou privés. 


\title{
G-quadruplex binding optimization by gold(III) insertion into the center of a porphyrin
}

Angélique Pipier ${ }^{a, b}$, Aurore De Rache ${ }^{c}$, Coralie Modeste ${ }^{a, b}$, Samir Amrane ${ }^{c}$, Emmanuelle MothesMartin $^{d}$, Jean-Luc Stiglianid ${ }^{d}$ Patrick Calsou, ${ }^{\mathrm{a}, \mathrm{b}}$, Jean-Louis Mergny ${ }^{\mathrm{c}, \mathrm{e}}$, Geneviève Pratvield, Dennis Gomez*a,b

a Institut de Pharmacologie et Biologie Structurale, IPBS, Université de Toulouse, CNRS, UPS, Toulouse, France.

${ }^{b}$ Equipe Labellisée Ligue Contre le Cancer.

c ARNA Laboratory, IECB, Inserm U1212, CNRS UMR 5320, Université de Bordeaux, Bordeaux, France.

d LCC-CNRS, CNRS, Université de Toulouse, UPS, Toulouse, France.

e Institute of Biophysics of the CAS, v.v.i., Královopolská 135, 61265 Brno, Czech Republic.

\begin{abstract}
Porphyrins represent a valuable class of ligands for G-quadruplex nucleic acids. Herein, we evaluate the binding of cationic porphyrins metallated with gold(III) to G-quadruplex DNA and we compare it with other porphyrin derivatives. The G-quadruplex stabilization capacity and the selectivity of the various porphyrins were evaluated by biophysical and biochemical assays. The porphyrins were also tested as inhibitors of telomerase. It clearly appeared that the insertion of gold(III) ion in the center of the porphyrin increases the binding affinity of the porphyrin for the G-quadruplex target. Together with modelling studies, it is possible to propose that the insertion of the square planar gold(III) ion adds an extra positive charge on the complex and decreases the electron density in the porphyrin aromatic macrocycle, both properties being in favour of stronger electrostatic and $\pi$-staking interactions.
\end{abstract}

\section{Keywords}

Quadruplex; Drug DNA interactions; gold-porphyrin; stacking; quantum mechanics 


\section{Introduction}

Single-stranded G-rich DNA and RNA sequences can adopt a particular conformation called a G-quadruplex (G4). ${ }^{1}$ Several articles demonstrating that G-quadruplexes have important functions in vivo have been published (for reviews ${ }^{2-4}$ ), including recent reports. ${ }^{5-11}$ Some of the strongest evidences for the existence of G-quadruplex structures in vivo come from the characterization of small compounds that bind and stabilize G-quadruplex structures, i.e. G-quadruplex ligands. ${ }^{12-14}$

Bioinformatic analysis of the human genome, based on the $\mathrm{G}_{3+}-\mathrm{N}_{1-7}-\mathrm{G}_{3+}-\mathrm{N}_{1-7}-\mathrm{G}_{3+}-\mathrm{N}_{1-7}-\mathrm{G}_{3+}$ consensus sequence, indicates that it contains as many as 370,000 sequences of potential Gquadruplex structure (PQS). ${ }^{15,} 16$ Using more recent approaches, ${ }^{17,} 18$ more than 700,000 G4-forming sequences were found. ${ }^{18}$ Nevertheless, in cells, only few tens of thousands are accessible to a G4specific antibody. ${ }^{11}$ Interestingly, PQSs are enriched on telomeres and embedded within promoters of human oncogenes, two potential targets for anti-cancer therapies. Indeed, on telomeres, it has been shown that the stabilization of G4 structures by small compounds inhibits the telomerase protein, a key enzyme playing an essential role in the cellular immortalization process leading to cancer. ${ }^{19}$

For some PQS, there is good evidence that the quadruplex structure affects transcriptional ${ }^{20-}$ 23 and post-transcriptional processes. ${ }^{24-33}$ A prominent example is found in the c-MYC gene, which has an upstream PQS that represses transcription. This repression is strengthened by the addition of the porphyrin G-quadruplex ligand TMPyP4. ${ }^{20}$ Similar effects of PQS on KRAS, $c-K I T, B C L 2^{21,22,34-36}$ and $c-\mathrm{SRC}^{37}$ expression have also been reported.

At the post-transcriptional level, we and others have described the potential impact of Gquadruplex structures on alternative splicing of mRNAs encoding telomerase ${ }^{24}$ and P53. ${ }^{38}$ Gquadruplex RNA structures have been implicated in mRNA processing, ${ }^{28,} 32$ transport ${ }^{31}$ and in translational regulation. ${ }^{25-27,29,30,39}$ Taken together these data support that G-quadruplex structures can be considered as targets for the development of therapeutic drugs in order to modulate both telomere maintenance and genetic expression, particularly in cancer cells. However, for Gquadruplex ligand-based therapeutics to become a reality a high level of specificity for a particular Gquadruplex associated to a high affinity-binding constant for the specific target is required.

A detailed picture of quadruplex structure is emerging and it is possible to develop a rational approach to the design and optimization of high affinity G-quadruplex stabilizing compounds. ${ }^{40,}, 41$ The desirable features of these stabilizing molecules are (i) a $\pi$-delocalized system that is able to stack on the face of a guanine quartet and, (ii) positively charged substituents that will interact with the 
negatively charged phosphates and the grooves and loops of the quadruplex. Specificity might come from further decoration that might allow additional interactions with grooves and/or loops.

Porphyrin-based G-quadruplex ligands are noteworthy compounds due to their very promising G-quadruplex binding properties. ${ }^{42}$, 43 The interaction of their relatively large planar aromatic region with quadruplex is due to $\pi$-stacking interaction with an external guanine quartet. Moreover, it is possible to insert a metal ion in the central cavity of the porphyrin and to modify the substituents at the periphery of the macrocycle. Porphyrins with bulky and positively-charged substituents at the four meso-positions led to highly specific ligands for G4 DNA with respect to duplex DNA. ${ }^{44-50}$ Their binding affinity constants to $\mathrm{G} 4$ can reach $10^{7} \mathrm{M}^{-1}$ or higher. The insertion of different metal ions in the porphyrin core, was studied in previous works. The different metal ions afforded some modulation in the binding properties of the porphyrins towards G-quadruplex DNA. ${ }^{47}$, ${ }^{51}$ Although the effect of metal ions was more noticeable in some series of porphyrins compared to others, the general trend is that insertion of metal ions with two axial ligands decreases the binding affinity while insertion of nickel(II), which does not have strong axial ligands, does not.

In the present work, the concept of decreasing the electron density of the porphyrin macrocycle to improve $\pi$-stacking while maintaining the planar character of the porphyrin was tested with the insertion of the square planar gold(III) ion in the center of the porphyrin. In addition, this gold(III) ion insertion adds a positive charge, which should also participate in the overall affinity for DNA. We show that incorporation of this particular three-charged ion with a planar coordination sphere increases the binding affinity with respect to both the non-metallated and metallated porphyrin analogous and provides an efficient G-quadruplex ligand. Moreover, using biochemical assays we also show that gold(III) insertion significantly improve the anti-telomerase activity of porphyrin compounds opening new perspectives for the design of porphyrin-based anti-cancer molecules. To our knowledge, there has not been much detailed study devoted to G4-ligands based on gold(III) complexes. ${ }^{43,52-55}$

\section{Results and discussion}

\section{The G4-ligands}

All the porphyrins used in the present work carry four positively charged meso-substituents (Scheme 1). The meso-tetrakis(4- $N$-methylpyridiniumyl)porphyrin (TMPyP4) has four $4-N$-methyl pyridiumyl substituents. The non-metallated (TMPyP4) and the gold(III) derivative (AuTMPyP4) were used. The meso-tetrakis(4-( $N$-methyl-pyridinium-2-yl)-phenyl)porphyrin (referred to as MA) bears four bulky substituents consisting of an $\mathrm{N}$-pyridinium-2-yl entity separated from the tetrapyrrole core by a 
phenyl ring. It was prepared in the form of the non-metallated porphyrin ( $\mathrm{H} 2 \mathrm{MA})$ or as the manganese(III) (MnMA), nickel(II) (NiMA), the cobalt(III) (CoMA) and the gold(III) (AuMA) complex. In addition, another cationic manganese porphyrin derivative (MnLB) was used as a reference compound..$^{56}$ The counter ions are chloride ions.

\section{Strong and selective binding of AuMA to G4 structures}

To evaluate the binding of gold(III) porphyrins to G-quadruplex structures we performed FRET melting assays. ${ }^{57,58}$ In this assay, the interaction of ligands with G4 structures is monitored by the increase of the half melting temperature $\left(T_{1 / 2}\right)$ of the G4-forming oligonucleotide F21T. The stabilization of the G4 structure formed by F21T is expressed by the $\Delta T_{1 / 2}$ value resulting from the differences of half melting temperatures measured with or without ligands. In $\mathrm{K}^{+}$conditions, the addition of 2 molar equivalents of AuMA $(0.4 \mu \mathrm{M})$ relative to F21T concentration $(0.2 \mu \mathrm{M})$ induces an increasing of the $T_{1 / 2}$ of $32.4{ }^{\circ} \mathrm{C}\left(T_{1 / 2} F 21 T=53.2{ }^{\circ} \mathrm{C} \pm 0.2, F 21 T\right.$ eq AuMA $\left.=85.6{ }^{\circ} \mathrm{C} \pm 0.7\right)$. When compared to both homologous porphyrins, the metal-free H2MA $\left(\mathrm{T}_{1 / 2} \mathrm{~F} 21 \mathrm{~T}\right.$ 2eq H2MA $=60.3^{\circ} \mathrm{C} \pm$ $0.5)$ and the manganese $M n M A\left(T_{1 / 2} F 21 T\right.$ 2eq MnMA $\left.=72.6^{\circ} \mathrm{C} \pm 1.0\right)$, AuMA induces a significantly stronger thermal stabilization of F21T oligonucleotide that indicates a better ability of AuMA to interact with G4-structures (Figure 1a). Unlike the first-generation porphyrin TMPyP4, MA compounds carry bulky substituents at the four meso-positions. Because we and others have shown in previous works that meso-substitutions significantly improve the binding of porphyrins to G4 structures ${ }^{44-50}$ we also investigated the impact of gold(III) insertion on the binding of TMPyP4 to G4structures. As shown in Figure 1a, the insertion of gold(III) in the TMPyP4 core provokes a slight but significant increase of the F21T thermal stabilization compared to the classical TMPyP4 compound $\left(\mathrm{T}_{1 / 2} \mathrm{~F} 21 \mathrm{~T}\right.$ 2eq TMPyP4 $=71.7^{\circ} \mathrm{C} \pm 0.1, \mathrm{~T}_{1 / 2} \mathrm{~F} 21 \mathrm{~T}$ 2eq AuTMPyP4 $\left.=74.8^{\circ} \mathrm{C} \pm 0.4\right)$. Taken together, FRET assays show that the insertion of a gold(III) ion into the center of the porphyrin cores has a general beneficial effect on the ability of porphyrin derivatives to stabilize G4 structures.

Selective binding of AuMA to G4 structures vs both duplex and single-stranded DNA was evaluated in FRET competition assays. In this assay, increasing concentrations of duplex or singlestranded DNA (5, 20 and 50 molar equivalents relative to F21T) were added to the complex formed by the F21T oligonucleotide in the presence of 2 molar equivalents of G4 ligands. As shown on Figure 1b, AuMA shows some selective binding to G4 structures compared to duplex and single-stranded DNA, as more than 50-fold higher concentrations of both competitors are required to cause a thermal destabilisation above $30^{\circ} \mathrm{C}$, which corresponds to the shift of the $T_{1 / 2}$ of $F 21 \mathrm{~T}$ in the presence of 2 molar equivalents of AuMA. Although a significant F21T thermal destabilisation was observed 
upon the addition of 5, 20 and 50 molar equivalents of competitors, that indicates that the selectivity of AuMA for G4 structures remains moderate compared to some highly selective G4 ligands described in literature, the selectivity of AuMA for G4 structures is significantly higher than that observed for TMPyP4, as both competitors have a major impact on the $\mathrm{T}_{1 / 2}$ of F21T-TMPyP4 complexes compared to F21T-AuMA complexes. Moreover, while both competitors induce a similar decrease of the half melting temperature of the G4 stabilized by TMPyP4 (about $20{ }^{\circ} \mathrm{C}$ in the presence of 50 molar equivalents of both competitors), AuMA shows a much weaker interaction with single-stranded DNA relative to duplex DNA $\left(\Delta \Delta \mathrm{T}_{1 / 2}=-17.2{ }^{\circ} \mathrm{C}\right.$ and $-11.0^{\circ} \mathrm{C}$ in the presence of 50 molar equivalents of duplex and single-stranded DNA, respectively) (Figure 1b). Taken together these results indicate that AuMA has a better binding affinity and selectivity for G4 structures than TMPyP4.

Because the strong $\mathrm{G} 4$ stabilization induced by AuMA could be dependent on particular interactions with F21T primary sequence, we also tested AuMA and other metallated-MA porphyrin derivatives for their ability to stabilize other G4-forming sequences that are known to adopt different conformations. In this experiment, eight different G4 forming sequences where tested; parallel G4 forming sequences such as F25cebT, ${ }^{59} \mathrm{FmycT},{ }^{60}$ and FTRF2RT; ${ }^{61}$ antiparallel G4 conformations such as FBom $17 T^{62}$ and F21CTAT. ${ }^{63}$ In addition we also tested the G4 structure from the human telomeric RNA. ${ }^{64}$ Finally, the FdxT oligonucleotide was used as non-G4-forming sequence, as it folds into a duplex. As shown on Figure 1c, AuMA compound stabilizes all the G4 structures. Moreover, compared to other metallated-MA derivatives, AuMA induces a stronger G4 thermal stabilization independent on both topology and primary sequence of oligonucleotide used in this experiment. This may be explained by the planar geometry of the gold(III) coordination sphere and by the higher positive charge of the gold(III) complex. H2MA and NiMA are also planar porphyrins but they carry only four positive charges and the nickel ion induces less electron deficiency in the aromatic cycle of the porphyrin. In the case of MnMA and CoMA, carrying five positive charges, the central metal has two water molecules as axial ligands (octahedral geometry) that might hinder close $\pi$-stacking interaction with the G-quadruplex.

In order to both confirm and further characterize the binding and the selectivity of AuMA for G4 structures, we performed a qPCR stop assay. This method derives from the classical PCR stop assay described in the literature, ${ }^{65}$ which is based on the ability of G4 structures to block DNA polymerases during PCR amplification. The stabilization of G4 structures by G4 ligands is expected to provoke a stronger inhibition of DNA amplification. Using this assay, we analysed the impact of AuMA on the amplification of two G4-containing sequences relative to a control sequence without any potential to form a G4 structure. The $21 \mathrm{G}$ sequence contains the G-rich motif of the human 
telomeric DNA and the Pu22 sequence contains the G-rich motif present into the NHE III1 region of the human c-myc promoter. As shown in Figure 2, AuMA inhibits the amplification of DNA fragments in a dose-dependent manner. Measured $I_{50}$ values for $21 \mathrm{G}$ and Pu22 are $0.04 \pm 0.01$ and $0.05 \pm 0.01$ $\mu \mathrm{M}$, respectively (Table 1 ). These values are 3 to 4 -fold lower than the $\mathrm{IC}_{50}$ for the control fragment $\left(\mathrm{IC}_{50}=0.15 \pm 0.01 \mu \mathrm{M}\right)$. The selectivity value is probably underestimated because only 16 bases of 93 bases composing the amplified region are engaged in the G4 formation. Nevertheless, the qPCR stop assay results indicate a preferential interaction of AuMA with G4-containing DNAs. Compared to TMPyP4, AuMA inhibits the amplification of G4 containing sequences at 10-fold lower concentrations $\left(\mathrm{IC}_{50}\right.$ TMPyP4 21G $\left.=0.35 \pm 0.02 \mu \mathrm{M}, \mathrm{Pu} 22=0.45 \pm 0.05 \mu \mathrm{M}\right)$ that confirms the better affinity of AuMA for G4 structures relative to TMPyP4. In this assay, TMPyP4 presents a very weak selectivity for G4carrying sequences compared to AuMA (Table 1), that partially disagrees with FRET competition data (Figure 1b) that showed a selective binding of TMPyP4 to G4 structures compared to both duplex and single-stranded DNA. Nevertheless, the weak selectivity of TMPyP4 for G4 structures vs both duplex and single-stranded DNAs has been previously reported. ${ }^{66}$ Moreover, we have observed strong interactions between TMPyP4 and proteins (data not shown) that could explain non-specific inhibition of DNA amplification through TMPyP4-polymerase interactions.

Stabilization of G4 structures on telomeric sequences leads to the inhibition of telomere extension by the telomerase protein. Telomere extension plays an essential role in cancer establishment, as telomeric maintenance is a crucial step of cellular immortalization. To evaluate the impact of AuMA on telomerase activity, therefore on telomere extension, we performed TRAP-G4 assay, that was developed to evaluate the inhibition of telomere-extension by G4 ligands and to discriminate between the inhibition induced by G4 stabilization and the potential effects of ligands on the catalytic activity of the telomerase. ${ }^{67}$ As shown in Table 2, AuMA is highly active on telomere extension as this molecule exhibits an $\mathrm{IC}_{50}$ of $0.04 \pm 0.01 \mu \mathrm{M}$ (IC ${ }_{50}$ TSG4). In this assay, the selectivity of AuMA for G4 structures compared to duplex DNA is 7-fold. This value, obtained from de ratio of Taq polymerase inhibition ( $I C_{50}$ for the amplification of the ITAS internal control) to the inhibition of telomerase ( $\mathrm{IC}_{50}$ for the amplification of TSG4 fragment), is relatively close to the selectivity value obtained from qPCR stop assays. When the telomerase inhibition activity of AuMA was compared to the telomerase inhibition induced by $\mathrm{H} 2 \mathrm{MA}, \mathrm{MnMA}$, and MnLB, which was previously described as the most potent and selective porphyrin-based G4 ligand, ${ }^{56}$ AuMA appears as a better telomerase inhibitor in vitro. Comparison of the selectivity values between these different molecules indicates that the gain in telomerase inhibition activity does not have a major impact on selectivity (Table 2 ).

In summary, FRET assays show that the insertion of $\mathrm{Au}^{3+}$ in the center of porphyrins improves the stabilization of G4 structures by these compounds. Nevertheless, the impact of gold(III) insertion 
on G4 stabilization is stronger in the MA series compared to the TMPyP4 derivatives. It is difficult to find the rationale for this difference. For the MA series, the thermal stabilization induced by the AuMA is globally higher than the thermal stabilization provoked by other metallated-MA molecules. The Au3+ ion is the only example of metal ion in the series with an oxidation state of $+I I I$ and a square planar geometry. Thus, based on global results the insertion of a gold(III) ion in the center of the porphyrin significantly improves the interaction of porphyrins with G4 DNA.

Because a significant increase in affinity for G4 structures may be accompanied by a loss of selectivity, we also evaluated the impact of gold(III) insertion on the selectivity towards G4 structures over duplex or single-stranded DNA. FRET competition and qPCR stop analyses showed that gold(III) derivative AuMA is significantly selective for $\mathrm{G} 4$ structures over non-G4 forming DNAs. In FRET competition assays, more than 50 molar equivalents of both duplex and single-stranded DNA are required to completely remove the AuMA porphyrin from the G4. In addition, we observed that the selectivity of AuMA for G4 DNAs is significantly higher than the selectivity of TMPyP4 towards the same G4s. Thus, the incorporation of a gold(III) ion in the porphyrin core increases the binding affinity for G4 structures and maintains the selectivity over duplex and single-stranded DNA.

Using FRET assay we also showed that the thermal stabilization of G4 structures induced by AuMA is independent on both G4 topology and of the sequence of G4-forming oligonucleotides. This assay also confirmed the impact of gold(III) insertion on the binding affinity for G4 structures, as AuMA is clearly more active on all G4-forming sequences than other MA-series derivatives.

Finally, we have shown that thanks to its binding and selectivity properties for G4 structures, the AuMA compound is a very good inhibitor of telomerase activity in vitro.

To better understand the excellent binding properties of AuMA we performed modelling studies.

\section{Molecular modelling studies}

We looked at the distribution of charges within the porphyrin macrocycle. The net Mulliken atomic charges of the H2MA and AuMA porphyrins computed at the level of BPW91/6-311+G(d,p) and their color-coding are shown in Figure S1 and S2, respectively. The core of the non-metallated porphyrin, formed by $\mathrm{C}$ - and $\mathrm{N}$-atoms of the pyrrole units, shows slightly positive atomic charges, while the two $\mathrm{H}$-atoms linked to the $\mathrm{N}$-atoms of the pyrroles are markedly positive (Figure $\mathrm{S} 1$ ). The addition of the gold(III) ion in the center of the porphyrin leads to a significant modification of the distribution of the charges (Figure S2). The electrophilic character of the $\mathrm{Au}(\mathrm{III})$ ion causes electron density to be drawn towards the center of the ring. As a consequence, the gold neighbor surrounding atomic crown 
becomes strongly positive. Thus, the porphyrin macrocycle is more electron deficient in the case of AuMA. This is in line with a better affinity of AuMA for the G-quadruplex DNA since the porphyrin is probably anchored to G4 by both electrostatic interaction (AuMA has an extra positive charge compared to $\mathrm{H} 2 \mathrm{MA}$ ) and $\pi$-stacking interaction (aromatic macrocycle more electron deficient).

Moreover, the insertion of the gold(III) ion in the center of the porphyrin leads to notable effects on the distribution of the molecular orbitals. Firstly, the energetic level of the frontier molecular orbitals (FMOs) of AuMA is strongly lowered compared to that of H2MA. The difference clearly appears in Figure 3, which displays the five first HOMOs and LUMOs energy levels of H2MA and AuMA. The energy of the LUMOs of AuMA is in the same range as the HOMOs of H2MA. Secondly, the organization of the MOs of the two porphyrins is significantly different. For AuMA, the first $\pi$-antibonding MOs are the LUMO +1 and LUMO +2 . They are localized in the central porphyrin ring and their energy are -12.29 and $-12.30 \mathrm{eV}$, respectively (Figure S3). In the case of H2MA, the first ?]-type MOs found into the porphyrin ring are the LUMO +4 and LUMO +5 , their energy level is higher: -9.47 and $-9.46 \mathrm{eV}$, respectively (Figure S4). The $\pi$-stacking between the porphyrin and the Gquadruplex might be partially explained by a donor-acceptor overlap between the orbitals of the two structures. As the energies of the LUMOs of AuMA that can interact are significantly lower than that of H2MA, AuMA may exhibit a much tighter binding to G4-DNA than H2MA.

\section{Conclusion}

The binding of aromatic ligands to G-quadruplex nucleic acids involves electrostatic interactions with the negatively charged phosphates and $\pi$-stacking interactions with the external G-quartet. Porphyrins carrying four positive charges at the meso-substituents proved to be good G-quadruplex ligands. The nature of the four substituents influences the selectivity of the compound, the MA porphyrin being a much better ligand relative to TMPyP4 in this respect. To further increase the binding affinity of the porphyrin ligand for G4 DNA it is possible to insert a metal ion in the center of the porphyrin aromatic macrocycle. The resulting metal complex is highly stable due to the suitable coordination site afforded by the porphyrin core. The introduction of a three positively charged gold(III) ion with a square planar geometry (no axial ligand on the metal) afforded gold-porphyrins endowed with a noticeable higher affinity for G-quadruplex DNA. Indeed, an extra positive charge and a decrease in electron density in the aromatic scaffold of the porphyrin had an obvious effect on the binding capacity of the ligand. Up to now, no other metal ion showed such an effect. $\mathrm{Ni}^{2+}, \mathrm{Cu}^{2+}$, $\mathrm{Pt}^{2+}$, and $\mathrm{Zn}^{2+}$ do not add any charge on the metal complex, and metal ions such as $\mathrm{Mn}^{3+}$ and 
$\mathrm{Co}^{3+}$ bear axial ligands that probably imply steric hindrance in interaction. Among the porphyrin derivatives tested in the present work the bulky AuMA showed excellent binding capacity toward G4.

\section{Experimental section}

\section{General}

The porphyrins were prepared as previously described. ${ }^{46,51,56,68,69}$ The metallation of H2MA with gold(III) is detailed in the Supporting Information. All other chemicals were purchased from commercial sources and were used as supplied otherwise stated.

\section{TRAP-G4 assay}

Telomerase competent protein extract was prepared from A549 cells: cells were lysed for $30 \mathrm{~min}$ on ice using CHAPS buffer with $5 \mathrm{mM} \beta$-mercaptoethanol. The lysate was centrifuged at $10000 \mathrm{rpm}$ for 10 min at $4{ }^{\circ} \mathrm{C}$ and the supernatant collected, stored at $-80^{\circ} \mathrm{C}$, and used as the telomerase source. TRAP-G4 assays was performed as described. ${ }^{67}$ Briefly, assays were performed in a $25 \mu \mathrm{L}$ reaction mixture containing: $20 \mathrm{mM}$ Tris- $\mathrm{HCl}(\mathrm{pH} 8.0), 50 \mu \mathrm{M}$ deoxynucleotide triphosphates, $1.5 \mathrm{mM} \mathrm{MgCl}$, $63 \mathrm{mM} \mathrm{KCl}, 1 \mathrm{mM}$ EGTA, $0.005 \%$ Tween 20, $20 \mu \mathrm{g} / \mathrm{mL}$ BSA, $150 \mathrm{nM}$ of primer NT (5'ATCGCTTCTCGGCCTTTT-3'), 200 aM of TSNT (5'-ATTCCGTCGAGCAGAGTTAAAAGGCCGAGAAGCGAT$\left.3^{\prime}\right), 450 \mathrm{nM}$ of primer CXext (5'-GTGCCCTTACCCTTACCCTTACCCTAA-3'), $360 \mathrm{nM}$ of primer TS (5'AATCCGTCGAGCAGAGTT-3') and 70 nM of TSG4 primer (5'-GGGATTGGGATTGGGATTGGGTT-3'). The reaction was completed with 1 unit of Dream Taq DNA polymerase and $200 \mathrm{ng}$ of telomerase competent protein extract. Telomerase elongation step was performed $\left(15 \mathrm{~min}\right.$ at $30^{\circ} \mathrm{C}$ ) followed by a PCR amplification step ( $30 \mathrm{cycles}$ of: $30 \mathrm{sec}$ at $95{ }^{\circ} \mathrm{C}, 30 \mathrm{sec}$ at $52{ }^{\circ} \mathrm{C}$ and $30 \mathrm{sec}$ at $72{ }^{\circ} \mathrm{C}$, followed by $30 \mathrm{sec}$ at $72{ }^{\circ} \mathrm{C}$ ). After amplification, a $10 \mu \mathrm{L}$ aliquot was loaded onto a $12 \%$ non-denaturing acrylamide gel (19:1) in TBE and electrophoresed at $180 \mathrm{~V}$ for $1 \mathrm{~h}$. Gels were stained with SYBR Green I (Molecular probes) and digitalized by a Photoimager (Bio-Rad). TRAPG4 assays were performed in triplicate.

\section{G4 FRET melting assays}

The ligand-induced thermal stabilisations $\left(\Delta T_{1 / 2}\right)$ were determined from FRET-melting experiments carried out in 96-well plates on a CFX96 real-time PCR equipment (Bio-Rad). After an initial stabilisation at $20^{\circ} \mathrm{C}$ for $10 \mathrm{~min}$, the temperature was increased by a $0.5^{\circ} \mathrm{C}$ step every minute until $99^{\circ} \mathrm{C}$. The labelled oligonucleotide was dissolved in stock pH 7.2 buffer (10 mM lithium cacodylate; 
$90 \mathrm{mM}$ lithium chloride) to $100 \mu \mathrm{M}$ stock concentration and stored at $-20{ }^{\circ} \mathrm{C}$. The melting experiments were performed at a final $0.2 \mu \mathrm{M}$ strand concentration of F21T oligonucleotide with 1, 2 or 5 molar equivalents of ligands relative to F21T concentration. For FRET competition assays the ds26 duplex competitor or the sb27 single-stranded competitor were added to indicated concentrations. All oligonucleotides were purchased from Eurogentec. The measurement buffer consisted in $10 \mathrm{mM}$ lithium cacodylate $\mathrm{pH} 7.2$ buffer; $90 \mathrm{mM}$ lithium chloride; $10 \mathrm{mM}$ potassium chloride for DNA oligonucleotides. In the case of RNA oligonucleotides the salt concentrations in the measurement buffer were $99 \mathrm{mM}$ lithium chloride; $1 \mathrm{mM}$ potassium chloride. For each experimental condition three separate plates were tested using triplicated wells.

Oligonucleotides used in FRET assay :

\begin{tabular}{|l|l|}
\hline Name & Sequence 5'-3' $^{\prime}$ \\
\hline F25CebT & Fam-AGGGTGGGTGTAAGTGTGGGTGGGT-Tamra \\
\hline F21CTAT & Fam-GGGCTAGGGCTAGGGCTAGGG-Tamra \\
\hline FmycT & Fam-TGAGGGTGGGGAGGGTGGGTAA-Tamra \\
\hline FBom17T & Fam-GGTTAGGTTAGGTTAGG-Tamra \\
\hline FdxT & Fam-TATAGCTATA-hexaethylenglycol-TATAGCTATA-TAmra \\
\hline FTRF2RT & Fam-CGGGAGGGCGGGGAGGGC-Tamra \\
\hline F21RT & Fam-GGGUUAGGGUUAGGGUUAGGG-Tamra \\
\hline F21T & Fam-GGGTTAGGGTTAGGGTTAGGG-Tamra \\
\hline ds26 & CAATCGGATCGAATTCGATCCGATTG \\
\hline sb27 & GGCTATCGGTATGCGTATGGCTATCGG \\
\hline
\end{tabular}

\section{Real Time qPCR Stop assay}

The stabilization of G-quadruplex by G4 ligands was assess by Real Time qPCR assay derived from classical PCR stop assay as previously described. ${ }^{65}$ In this assay, one matrix sequence was amplified using two external oligonucleotides (Fwd 5'- TCAAGAAGGTGGTGAAGCAC-3' and Rev 5'CGCTGTTGAAGTCAGAGGAG-3') on a CFX96 real-time PCR equipment (Bio-Rad) using the SsoFast EvaGreen Supermix (Bio-Rad) in a final $10 \mu \mathrm{L}$ reaction containing: $5 \mathrm{pM}$ of matrix oligonucleotide, 500 $\mathrm{nM}$ of each external oligonucleotide and increasing concentrations of $\mathrm{G} 4$ ligand. Amplification conditions used in this assay are $95^{\circ} \mathrm{C}$ for $30 \mathrm{sec}$ and 40 cycles of $95^{\circ} \mathrm{C} 5 \mathrm{sec}$ and $60^{\circ} \mathrm{C}$ for $20 \mathrm{sec}$ with a plate reading after the end of each second step. To evaluate the specificity of G4 stabilization by G4 ligands three different matrix sequences were used: control matrix sequence (5'- TCA-AGA-AGGTGG-TGA-AGC-ACG-CGT-CGG-AGG-GCC-CAC-ACT-GAG-CAC-CTC-AAG-CGC-ATC-CTG-CGC-TCC-AGGTGG-TCT-CCT-CTG-ACT-TCA-ACA-GCG-3'), Pu22myc matrix sequence (5'- TCA-AGA-AGG-TGG-TGAAGC-ACG-AGG-GTG-GGG-AGG-GTG-GGG-AAG-CAC-CTC-AAG-CGC-ATC-CTG-CGC-TCC-AGG-TGG-TCTCCT-CTG-ACT-TCA-ACA-GCG-3') and the telomeric matrix sequence (5'- TCA-AGA-AGG-TGG-TGAAGC-ACG-GGT-TAG-GGT-TAG-GGT-TAG-GGG-CAC-CTC-AAG-CGC-ATC-CTG-CGC-TCC-AGG-TGG-TCTCCT-CTG-ACT-TCA-ACA-GCG-3'), the two last sequences containing a G4 motif from the human c-myc 
promoter or from the human telomeric sequence at the middle of the fragment. Amplification plots were analyzed using the CFX Maestro software (Bio-Rad) and the $\Delta \mathrm{Ct}$ method was used to evaluate the impact of ligands on PCR amplification. For each experimental condition, three separate plates were tested using triplicated wells.

\section{Modelling studies}

All the quantum calculations were performed using the GAUSSIAN 09.D01 program. ${ }^{70}$ Geometry optimizations of the porphyrins were performed with the BPW91 density functional and the 6$311+G(d, p)$ basis set. ${ }^{71}, 72$ Vibrational frequency calculations were performed to confirm the convergence to local minima.

\section{Acknowledgements}

We thank A. Guédin for technical assistance, we are grateful to Agence Nationale pour la Recherche (ANR) (Quarpdiems ANR-12-BSV8-0008-01), Cancéropole Grand Sud-Ouest (2016-E-10), Ligue Régionale contre le Cancer, comité de Dordogne (to JLM) and the SYMBIT project (reg. no. CZ.02.1.01/0.0/0.0/15_003/0000477) financed by the ERDF. 


\section{Tables}

Table 1 Data from qPCR stop assay: $I C_{50}$ values $(\mu \mathrm{M})$ and selectivity index

\begin{tabular}{|c|c|c|c|l|l|}
\hline \multirow{2}{*}{ ligand } & \multicolumn{3}{|c|}{$\mathrm{IC}_{50}(\mu \mathrm{M})^{\mathrm{a}}$} & \multicolumn{2}{c|}{ qPCR stop assay selectivity ${ }^{\mathrm{b}}$} \\
\cline { 2 - 6 } & control & $21 \mathrm{G}$ & Pu22-myc & control/21G & control/Pu22-myc \\
\hline TMPyP4 & $0.49 \pm 0.05$ & $0.35 \pm 0.02$ & $0.45 \pm 0.04$ & 1.4 & 1.1 \\
\hline AuMA & $0.15 \pm 0.01$ & $0.04 \pm 0.01$ & $0.05 \pm 0.01$ & 4.0 & 3.1 \\
\hline
\end{tabular}

The $\mathrm{IC}_{50}$ values correspond to the concentration required to inhibit $50 \%$ of the amplification.

${ }^{a}$ SD and statistical analyses result from three independent experiments performed in triplicate.

b Selectivity index corresponds to the ratio of the $\mathrm{IC}_{50}$ of control to the $\mathrm{IC}_{50}$ of $\mathrm{G} 4$ containing sequence.

Table 2 Data from TRAP-G4 assay: $I C_{50}$ values $(\mu \mathrm{M})$ and selectivity index

\begin{tabular}{|c|l|l|l|}
\hline ligand & \multicolumn{1}{|c|}{ IC $_{50}{\text { TSG4 }(\mu \mathrm{M})^{\mathrm{a}}}^{\mid}$} & IC $_{50}$ ITAS $(\mu \mathrm{M})^{\mathrm{a}}$ & TRAP G4 selectivity $^{\mathrm{b}}$ \\
\hline AuMA & $0.04 \pm 0.01$ & $0.28 \pm 0.03$ & 7.00 \\
\hline H2MA & $0.15 \pm 0.04$ & $1.35 \pm 0.05$ & 9.00 \\
\hline MnMA & $0.09 \pm 0.01$ & $0.87 \pm 0.02$ & 7.50 \\
\hline MnLB & $0.12 \pm 0.02$ & $0.90 \pm 0.03$ & 7.50 \\
\hline
\end{tabular}

The $\mathrm{IC}_{50}$ value corresponds to the concentration required to inhibit $50 \%$ of the amplification of the $\mathrm{TSG}_{4}$ fragment.

a Mean \pm standard deviation of duplicates.

b TRAP-G4 selectivity index corresponds to the ratio of the $\mathrm{IC}_{50}$ ITAS (internal control) to the IC 50 TRAP-G4. 


\section{Legends of Figures and Schemes}

Scheme 1. Structures of the used porphyrins.

Figure 1 Thermal stabilization of G4 structures by TMPyP4 and AuMA

a Thermal stabilization of the F21T oligonucleotide measured by melting FRET assays. Porphyrin derivatives were added to the reaction at 2 molar equivalents $(0.4 \mu \mathrm{M})$ with respect to F21T $(0.2$ $\mu \mathrm{M})$. The $\Delta \mathrm{T}_{1 / 2}$ value indicates the difference of melting temperature $(\mathrm{Tm})$ induced by the ligand. $\mathbf{b}$ Melting FRET competition assays. For competition assays 5, 20 and 50 molar equivalents of competitor double-stranded (ds26) and single-stranded (ss27) DNAs were added to the reaction in the presence of 2 molar equivalents of porphyrins. The $\Delta \Delta \mathrm{T}_{1 / 2}$ value indicates the decrease of melting temperature $(\mathrm{Tm})$ provoked by competitors in the presence of 2 molar equivalents of ligands. c Thermal stabilization of G4-forming sequences by MA-derivatives measured by FRET assays. Porphyrin derivatives were added to the reaction at 2.5 molar equivalents $(0.5 \mu \mathrm{M})$ with respect to oligonucleotides $(0.2 \mu \mathrm{M}) . \Delta \mathrm{T}_{1 / 2}$ values, $\mathrm{SD}$ and statistical analyses result from three independent experiments performed in triplicate. ${ }^{* * *} \mathrm{P}$ value of $0.0002, * * * * \mathrm{P}$ value $<0.0001$

Figure 2 Real Time qPCR Stop assay

Real Time qPCR amplifications of Control, 21G and Pu22-myc sequences were performed in the presence of increasing concentrations $(0.1,0.3,1.0,3.0,10$ and $30 \mu \mathrm{M})$ of TMPyP4 (left) and AuMA (right). Relative amplification was obtained from gene expression results based on the $\Delta C$ values relative to the amplification observed in the absence of ligand.

Figure 3 First five frontier occupied and unoccupied orbital energies of AuMA and H2MA (in eV) calculated at the level of BPW91/6-311+G(d,p). Blue and red horizontal lines show the levels of the LUMOs and HOMOs, respectively. 


\section{References}

1. S. Neidle and S. Balasubramanian, Quadruplex Nucleic Acids, RSC Biomolecular Sciences, Cambridge, 2006.

2. D. Rhodes and H. J. Lipps, Nucleic Acids Res., 2015, 43, 8627-8637.

3. P. Murat and S. Balasubramanian, Curr. Opin. Genet. Dev., 2014, 25, 22-29.

4. R. Hänsel-Hertsch, M. Di Antonio and S. Balasubramanian, Nat. Rev. Mol. Cell Biol., 2017, 18, 279-284.

5. G. Biffi, M. Di Antonio, D. Tannahill and S. Balasubramanian, Nat. Chem., 2014, 6, 75-80.

6. R. F. Hoffmann, Y. M. Moshkin, S. Mouton, N. A. Grzeschik, R. D. Kalicharan, J. Kuipers, A. H. Wolters, K. Nishida, A. V. Romashchenko, J. Postberg, H. Lipps, E. Berezikov, O. C. Sibon, B. N. Giepmans and P. M. Lansdorp, Nucleic Acids Res., 2016, 44, 152-163.

7. A. Piazza, M. Adrian, F. Samazan, B. Heddi, F. Hamon, A. Serero, J. Lopes, M. P. TeuladeFichou, A. T. Phan and A. Nicolas, EMBO J., 2015, 34, 1718-1734.

8. A. L. Valton, V. Hassan-Zadeh, I. Lema, N. Boggetto, P. Alberti, C. Saintome, J. F. Riou and M. N. Prioleau, EMBO J., 2014, 33, 732-746.

9. A. Laguerre, J. M. Wong and D. Monchaud, Sci. Rep., 2016, 6, 32141.

10. S. Q. Mao, A. T. Ghanbarian, J. Spiegel, S. Martinez Cuesta, D. Beraldi, M. Di Antonio, G. Marsico, R. Hansel-Hertsch, D. Tannahill and S. Balasubramanian, Nat. Struct. Mol. Biol., 2018, 25, 951-957.

11. R. Hansel-Hertsch, D. Beraldi, S. V. Lensing, G. Marsico, K. Zyner, A. Parry, M. Di Antonio, J. Pike, H. Kimura, M. Narita, D. Tannahill and S. Balasubramanian, Nature genetics, 2016, 48, 1267-1272.

12. D. Monchaud, C. Allain, H. Bertrand, N. Smargiasso, F. Rosu, V. Gabelica, A. De Cian, J. L. Mergny and M. P. Teulade-Fichou, Biochimie, 2008, 90, 1207-1223.

13. B. Maji and S. Bhattacharya, Chem. Commun., 2014, 50, 6422-6438.

14. S. Neidle, Nat. Rev. Chem., 2017, 1, 0041.

15. J. L. Huppert and S. Balasubramanian, Nucleic Acids Res., 2005, 33, 2908-2916.

16. A. K. Todd, M. Johnston and S. Neidle, Nucleic Acids Res., 2005, 33, 2901-2907.

17. A. Bedrat, L. Lacroix and J. L. Mergny, Nucleic Acids Res., 2016, 44, 1746-1759.

18. V. S. Chambers, G. Marsico, J. M. Boutell, M. Di Antonio, G. P. Smith and S. Balasubramanian, Nat Biotechnol, 2015, 33, 877-881.

19. A. De Cian, L. Lacroix, C. Douarre, N. Temime-Smaali, C. Trentesaux, J. F. Riou and J. L. Mergny, Biochimie, 2008, 90, 131-155.

20. A. Siddiqui-Jain, C. L. Grand, D. J. Bearss and L. H. Hurley, Proc. Natl. Acad. Sci. U. S. A., 2002, 99, 11593-11598.

21. H. Fernando, A. P. Reszka, J. Huppert, S. Ladame, S. Rankin, A. R. Venkitaraman, S. Neidle and S. Balasubramanian, Biochemistry, 2006, 45, 7854-7860.

22. M. I. Onyshchenko, T. I. Gaynutdinov, E. A. Englund, D. H. Appella, R. D. Neumann and I. G. Panyutin, Nucleic Acids Res., 2009, 37, 7570-7580.

23. J. Eddy, A. C. Vallur, S. Varma, H. Liu, W. C. Reinhold, Y. Pommier and N. Maizels, Nucleic Acids Res., 2011, 39, 4975-4983.

24. D. Gomez, T. Lemarteleur, L. Lacroix, P. Mailliet, J. L. Mergny and J. F. Riou, Nucleic Acids Res., 2004, 32, 371-379.

25. A. Arora, M. Dutkiewicz, V. Scaria, M. Hariharan, S. Maiti and J. Kurreck, Rna, 2008, 14, 12901296.

26. G. D. Balkwill, K. Derecka, T. P. Garner, C. Hodgman, A. P. Flint and M. S. Searle, Biochemistry, 2009, 48, 11487-11495.

27. S. Bonnal, C. Schaeffer, L. Creancier, S. Clamens, H. Moine, A. C. Prats and S. Vagner, J. Biol. Chem., 2003, 278, 39330-39336.

28. J. Christiansen, M. Kofod and F. C. Nielsen, Nucleic Acids Res., 1994, 22, 5709-5716. 
29. S. Kumari, A. Bugaut, J. L. Huppert and S. Balasubramanian, Nat. Chem. Biol., 2007, 3, 218221.

30. M. J. Morris and S. Basu, Biochemistry, 2009, 48, 5313-5319.

31. C. Schaeffer, B. Bardoni, J. L. Mandel, B. Ehresmann, C. Ehresmann and H. Moine, EMBO J., 2001, 20, 4803-4813.

32. W. I. Sundquist and S. Heaphy, Proc. Natl. Acad. Sci. U. S. A., 1993, 90, 3393-3397.

33. A. Cammas and S. Millevoi, Nucleic Acids Res., 2017, 45, 1584-1595.

34. S. Cogoi and L. E. Xodo, Nucleic Acids Res., 2006, 34, 2536-2549.

35. J. Amato, T. W. Madanayake, N. laccarino, E. Novellino, A. Randazzo, L. H. Hurley and B. Pagano, Chem. Commun., 2018, 54, 9442-9445.

36. P. Agrawal, C. Lin, R. I. Mathad, M. Carver and D. Yang, J. Am. Chem. Soc., 2014, 136, 17501753.

37. R. Rodriguez, K. M. Miller, J. V. Forment, C. R. Bradshaw, M. Nikan, S. Britton, T. Oelschlaegel, B. Xhemalce, S. Balasubramanian and S. P. Jackson, Nat. Chem. Biol., 2012, 8, 301-310.

38. V. Marcel, P. L. Tran, C. Sagne, G. Martel-Planche, L. Vaslin, M. P. Teulade-Fichou, J. Hall, J. L. Mergny, P. Hainaut and E. Van Dyck, Carcinogenesis, 2011, 32, 271-278.

39. D. Gomez, A. Guedin, J. L. Mergny, B. Salles, J. F. Riou, M. P. Teulade-Fichou and P. Calsou, Nucleic Acids Res., 2010, 38, 7187-7198.

40. S. Neidle, Curr. Opin. Struct. Biol., 2009, 19, 239-250.

41. S. M. Haider, G. N. Parkinson and S. Neidle, J. Mol. Biol., 2003, 326, 117-125.

42. E. Izbicka, R. T. Wheelhouse, E. Raymond, K. K. Davidson, R. A. Lawrence, D. Sun, B. E. Windle, L. H. Hurley and D. D. Von Hoff, Cancer Res., 1999, 59, 639-644.

43. D. F. Shi, R. T. Wheelhouse, D. Sun and L. H. Hurley, J. Med. Chem., 2001, 44, 4509-4523.

44. I. M. Dixon, F. Lopez, A. M. Tejera, J. P. Esteve, M. A. Blasco, G. Pratviel and B. Meunier, J. Am. Chem. Soc., 2007, 129, 1502-1503.

45. L. Sabater, M. L. Nicolau-Travers, A. De Rache, E. Prado, J. Dejeu, O. Bombarde, J. Lacroix, P. Calsou, E. Defrancq, J. L. Mergny, D. Gomez and G. Pratviel, J. Biol. Inorg. Chem., 2015, 20, 729-738.

46. L. Sabater, P. J. Fang, C. F. Chang, A. De Rache, E. Prado, J. Dejeu, A. Garofalo, J. H. Lin, J. L. Mergny, E. Defrancq and G. Pratviel, Dalton Trans., 2015, 44, 3701-3707.

47. J. Dejeu, T. Lavergne, J. Della Nora, E. Defrancq and G. Pratviel, Inorg Chim Acta, 2016, 452, 98-103.

48. R. Zhang, M. Cheng, L. M. Zhang, L. N. Zhu and D. M. Kong, ACS Appl. Mater. Interfaces, 2018, 10, 13350-13360.

49. P. Wang, L. Ren, H. He, F. Liang, X. Zhou and Z. Tan, Chembiochem : a European journal of chemical biology, 2006, 7, 1155-1159.

50. X. X. Huang, L. N. Zhu, B. Wu, Y. F. Huo, N. N. Duan and D. M. Kong, Nucleic Acids Res., 2014, 42, 8719-8731.

51. Patent, EP15306737.6, 2015.

52. R. W. Y. Sun, C. K. L. Li, D. L. Ma, J. J. Yan, C. N. Lok, C. H. Leung, N. Y. Zhu and C. M. Che, Chem.-Eur. J., 2010, 16, 3097-3113.

53. K. Suntharalingam, D. Gupta, P. J. Sanz Miguel, B. Lippert and R. Vilar, Chem.-Eur. J., 2010, 16, 3613-3616.

54. B. Bertrand, M. A. O'Connell, Z. A. E. Waller and M. Bochmann, Chem.-Eur. J., 2018, 24, 36133622.

55. Q. Cao, Y. Li, E. Freisinger, P. Z. Qin, R. K. O. Sigel and Z. W. Mao, Inorg. Chem. Front., 2017, 4, 10-32.

56. I. M. Dixon, F. Lopez, A. M. Tejera, J. P. Esteve, M. A. Blasco, G. Pratviel and B. Meunier, J. Am. Chem. Soc., 2007, 129, 1502-1503.

57. J. L. Mergny and J. C. Maurizot, ChemBioChem, 2001, 2, 124-132.

58. A. De Cian, L. Guittat, M. Kaiser, B. Sacca, S. Amrane, A. Bourdoncle, P. Alberti, M. P. TeuladeFichou, L. Lacroix and J. L. Mergny, Methods, 2007, 42, 183-195. 
59. S. Amrane, M. Adrian, B. Heddi, A. Serero, A. Nicolas, J. L. Mergny and A. T. Phan, J. Am. Chem. Soc., 2012, 134, 5807-5816.

60. A. Ambrus, D. Chen, J. Dai, R. A. Jones and D. Yang, Biochemistry, 2005, 44, 2048-2058.

61. D. Gomez, A. Guedin, J. L. Mergny, B. Salles, J. F. Riou, M. P. Teulade-Fichou and P. Calsou, Nucleic Acids Res., 2010, 38, 7187-7198.

62. S. Amrane, R. W. Ang, Z. M. Tan, C. Li, J. K. Lim, J. M. Lim, K. W. Lim and A. T. Phan, Nucleic Acids Res., 2009, 37, 931-938.

63. K. W. Lim, P. Alberti, A. Guedin, L. Lacroix, J. F. Riou, N. J. Royle, J. L. Mergny and A. T. Phan, Nucleic Acids Res., 2009, 37, 6239-6248.

64. A. Guedin, L. Lacroix and J. L. Mergny, Methods in molecular biology, 2010, 613, 25-35.

65. T. Lemarteleur, D. Gomez, R. Paterski, E. Mandine, P. Mailliet and J. F. Riou, Biochem. Biophys. Res. Commun., 2004, 323, 802-808.

66. J. Ren and J. B. Chaires, Biochemistry, 1999, 38, 16067-16075.

67. D. Gomez, J. L. Mergny and J. F. Riou, Cancer Res., 2002, 62, 3365-3368.

68. C. Romera, L. Sabater, A. Garofalo, M. D. I and G. Pratviel, Inorg. Chem., 2010, 49, 8558-8567.

69. C. Romera, O. Bombarde, R. Bonnet, D. Gomez, P. Dumy, P. Calsou, J. F. Gwan, J. H. Lin, E. Defrancq and G. Pratviel, Biochimie, 2011, 93, 1310-1317.

70. M. J. Frisch, G. W. Trucks, H. B. Schlegel, G. E. Scuseria, M. A. Robb, J. R. Cheeseman, G. Scalmani, V. Barone, B. Mennucci, G. A. Petersson, H. Nakatsuji, v. Caricato, X. Li, H. P. Hratchian, A. F. Izmaylov, J. Bloino, G. Zheng, J. L. Sonnenberg, M. Hada, M. Ehara, K. Toyota, R. Fukuda, Hasegawa, J. M. Ishida, T. Nakajima, Y. Honda, O. Kitao, H. Nakai, T. Vreven, J. Montgomery, J. A. , J. E. Peralta, F. Ogliaro, M. Bearpark, J. J. Heyd, E. Brothers, K. N. Kudin, V. N. Staroverov, T. Keith, R. Kobayashi, J. Normand, K. Raghavachari, A. Rendell, J. C. Burant, S. S. Iyengar, J. Tomasi, M. Cossi, N. Rega, J. M. Millam, M. Klene, J. E. Knox, J. B. Cross, V. Bakken, C. Adamo, J. Jaramillo, R. Gomperts, R. E. Stratmann, O. Yazyev, A. J. Austin, R. Cammi, C. Pomelli, J. W. Ochterski, R. L. Martin, K. Morokuma, V. G. Zakrzewski, G. A. Voth, P. Salvador, J. J. Dannenberg, S. Dapprich, A. D. Daniels, O. Farkas, J. B. Foresman, J. V. Ortiz, J. Cioslowski and D. J. Fox, Gaussian 09, Revision D.01, Gaussian, Inc., Wallingford CT 2013.

71. J. P. Perdew, J. A. Chevary, S. H. Vosko, K. A. Jackson, M. R. Pederson, D. J. Singh and C. Fiolhais, Phys. Rev. B, 1992, 46, 6671-6687.

72. A. D. Becke, Phys. Rev. A, 1988, 38, 3098-3100. 


\section{FIGURES}
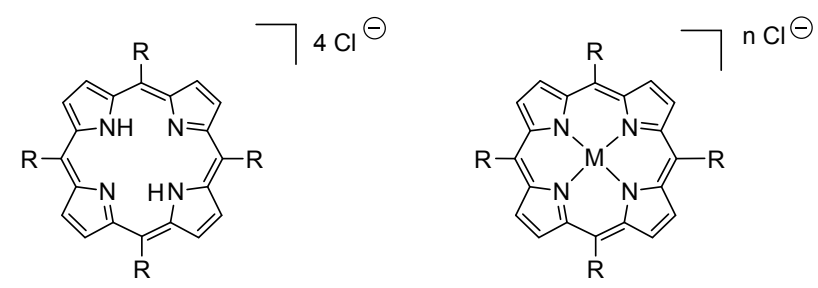

$\mathrm{R}={ }_{N^{\mathrm{N}}}^{\oplus}$ TMPyP4

$M=A u^{\prime \prime \prime}(n=5)$

AuTMPyP4

R=

$$
\begin{aligned}
& M=A u^{\text {III }}(n=5) \quad \text { AuMA } \\
& M=\mathrm{Ni}^{\prime \prime}(n=4) \quad \text { NiMA } \\
& \left\{\mathrm{M}=\mathrm{Mn}^{\mathrm{III}}\left(\mathrm{H}_{2} \mathrm{O}\right)_{2}(\mathrm{n}=5) \quad \mathrm{MnMA}\right. \\
& M=\mathrm{Co}^{\prime \prime \prime}\left(\mathrm{H}_{2} \mathrm{O}\right)_{2}(\mathrm{n}=5) \quad \text { CoMA } \\
& M=M^{\prime \prime \prime}\left(H_{2} O\right)_{2}(n=5) \quad M n L B
\end{aligned}
$$

Scheme 1 Structures of the used porphyrins 
a

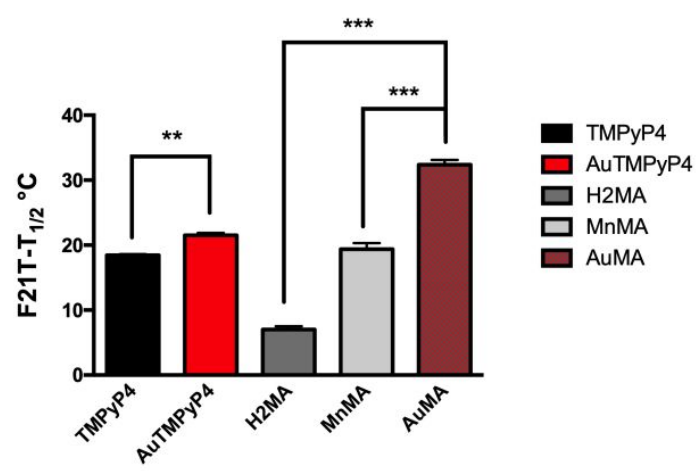

b
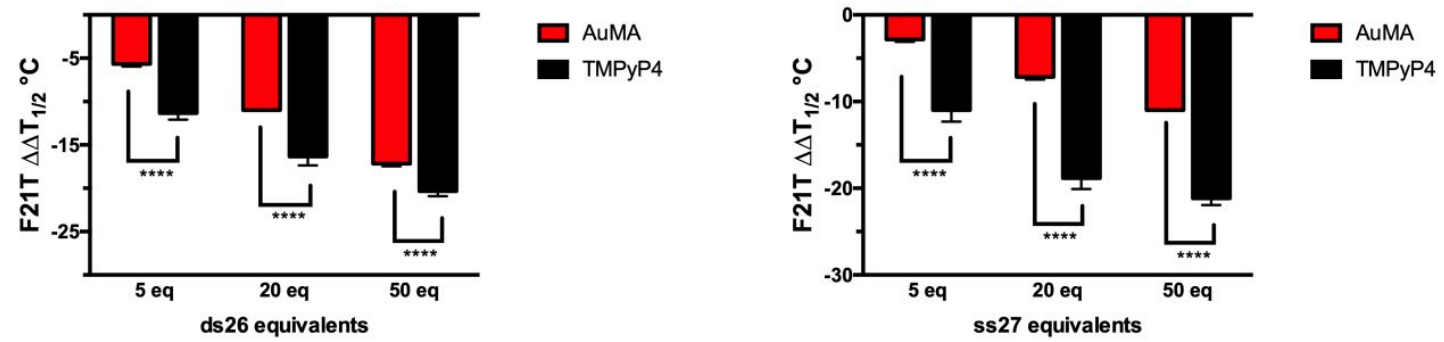

C

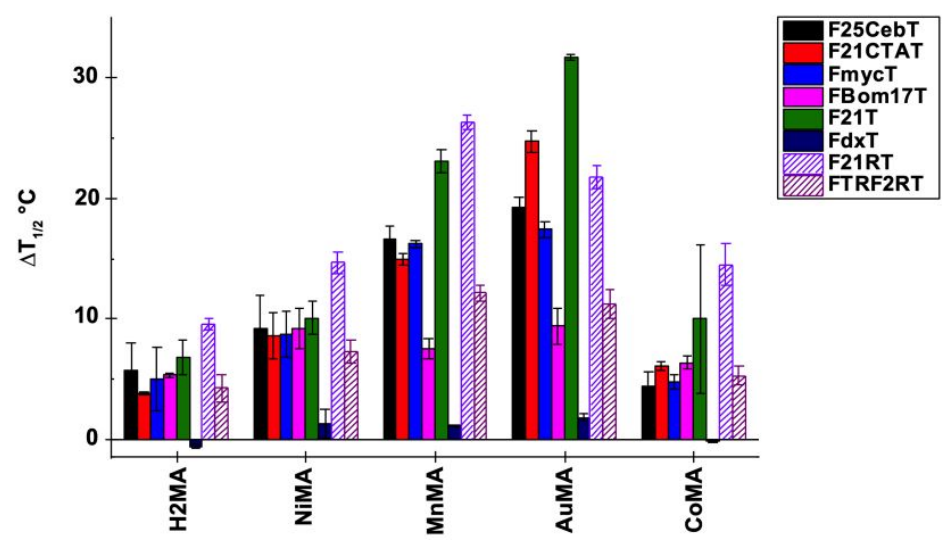

Figure 1 Thermal stabilization of G4 structures by TMPyP4 and AuMA

a Thermal stabilization of the F21T oligonucleotide measured by melting FRET assays. Porphyrin derivatives were added to the reaction at 2 molar equivalents $(0.4 \mu \mathrm{M})$ with respect to F21T $(0.2$ $\mu \mathrm{M})$. The $\Delta \mathrm{T}_{1 / 2}$ value indicates the difference of melting temperature $(\mathrm{Tm})$ induced by the ligand. $\mathbf{b}$ Melting FRET competition assays. For competition assays 5, 20 and 50 molar equivalents of competitor double-stranded (ds26) and single-stranded (ss27) DNAs were added to the reaction in the presence of 2 molar equivalents of porphyrins. The $\Delta \Delta T_{1 / 2}$ value indicates the decrease of melting temperature $(\mathrm{Tm})$ provoked by competitors in the presence of 2 molar equivalents of ligands. c Thermal stabilization of G4-forming sequences by MA-derivatives measured by FRET assays. Porphyrin derivatives were added to the reaction at 2.5 molar equivalents $(0.5 \mu \mathrm{M})$ with respect to oligonucleotides $(0.2 \mu \mathrm{M}) . \Delta \mathrm{T}_{1 / 2}$ values, $\mathrm{SD}$ and statistical analyses result from three independent experiments performed in triplicate. ${ }^{* * *} \mathrm{P}$ value of $0.0002, * * * * \mathrm{P}$ value $<0.0001$ 

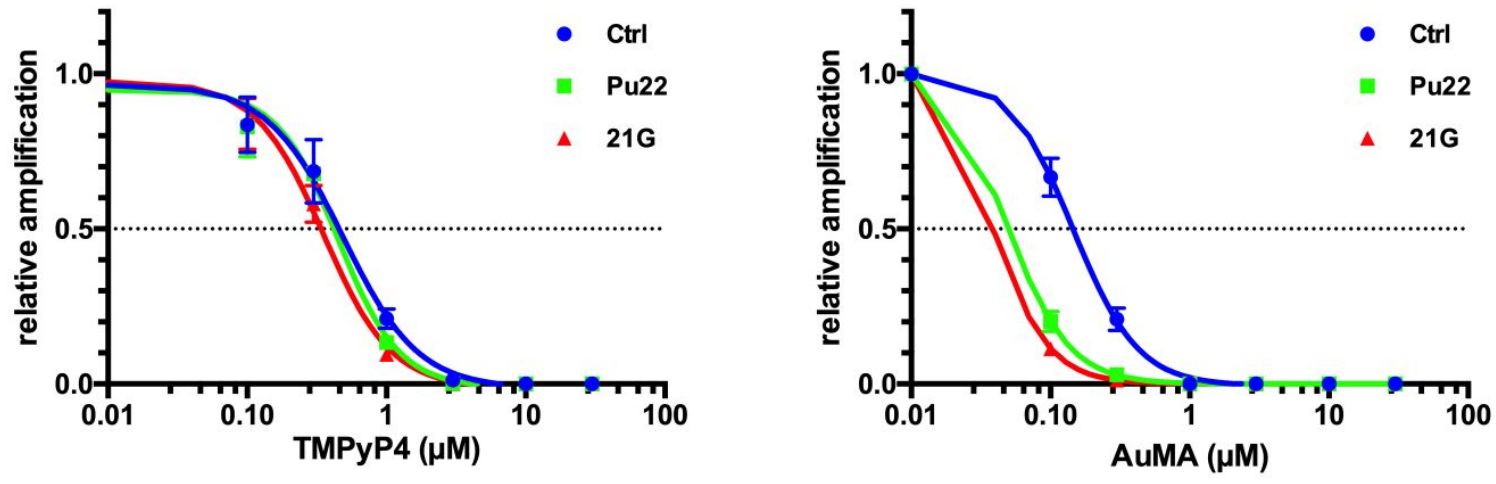

Figure 2 Real Time qPCR Stop assay. Real Time qPCR amplifications of Control, $21 \mathrm{G}$ and Pu22-myc sequences were performed in the presence of increasing concentrations $(0.1,0.3,1.0,3.0,10$ and 30 $\mu \mathrm{M}$ ) of TMPyP4 (left) and AuMA (right). Relative amplification was obtained from gene expression results based on the $\Delta \mathrm{Ct}$ values relative to the amplification observed in the absence of ligand. 


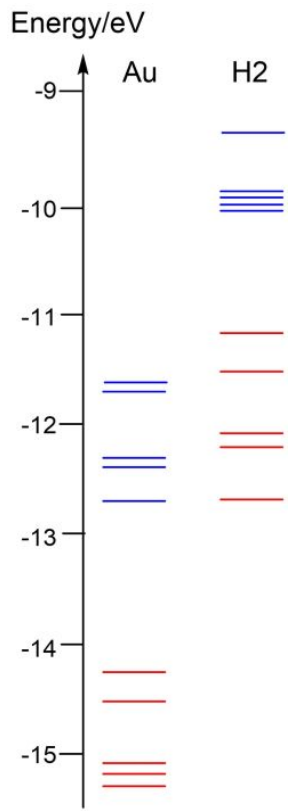

Figure 3 First five frontier occupied and unoccupied orbital energies of AuMA and H2MA (in eV) calculated at the level of BPW91/6-311+G(d,p). Blue and red horizontal lines show the levels of the LUMOs and HOMOs, respectively. 


\section{SUPPORTING INFORMATION}

\section{G-quadruplex binding optimization by gold(III) insertion into the center of a porphyrin}

Angélique Pipier, Aurore De Rache, Coralie Modeste, Samir Amrane, Emmanuelle Mothes-Martin, Jean-Luc Stigliani, Patrick Calsou, Jean-Louis Mergny, Geneviève Pratviel, Dennis Gomez

\section{Content}

- Mulliken atomic charges of H2MA (Figure S1) and AuMA (Figure S2).

- $\pi$-antibonding LUMOs of AuMA (Figure S3) and H2MA (Figure S4)

- Metalation of $\mathrm{H}_{2} \mathrm{MA}$ with $\mathrm{KAuCl}_{4}$.

- ${ }^{1} \mathrm{H}$ NMR spectrum of AuMA (Figure S5)

- HPLC analysis of AuMA (Figure S6) 

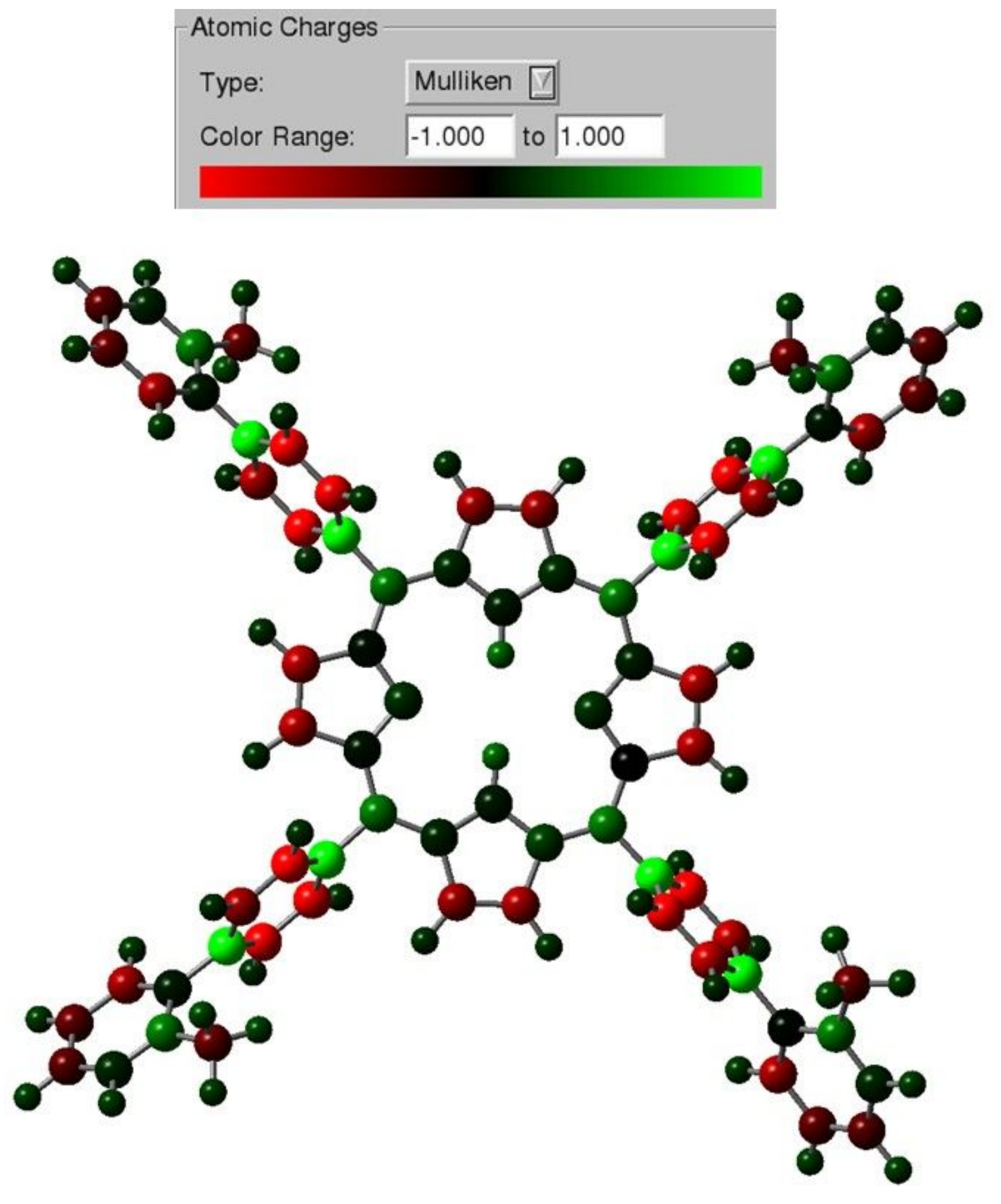

Figure S1. Calculated Mulliken atomic charges of the tetracationic non-metallated porphyrin H2MA. Color picture of the charges within a -1 to +1 color range. 

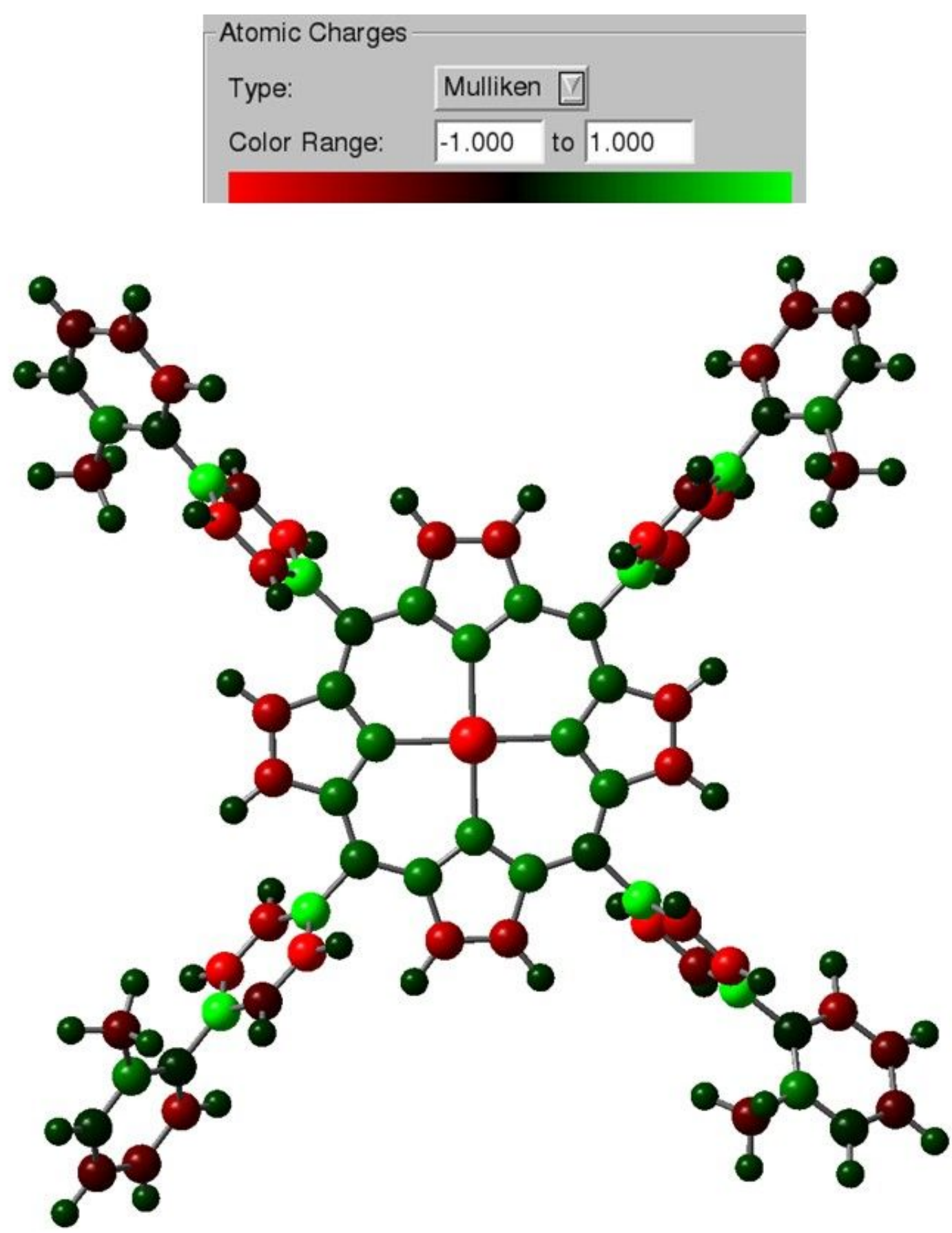

Figure S2. Calculated Mulliken atomic charges of the pentacationic gold(III)-porphyrin AuMA. Color picture of the charges within a -1 to +1 color range. 

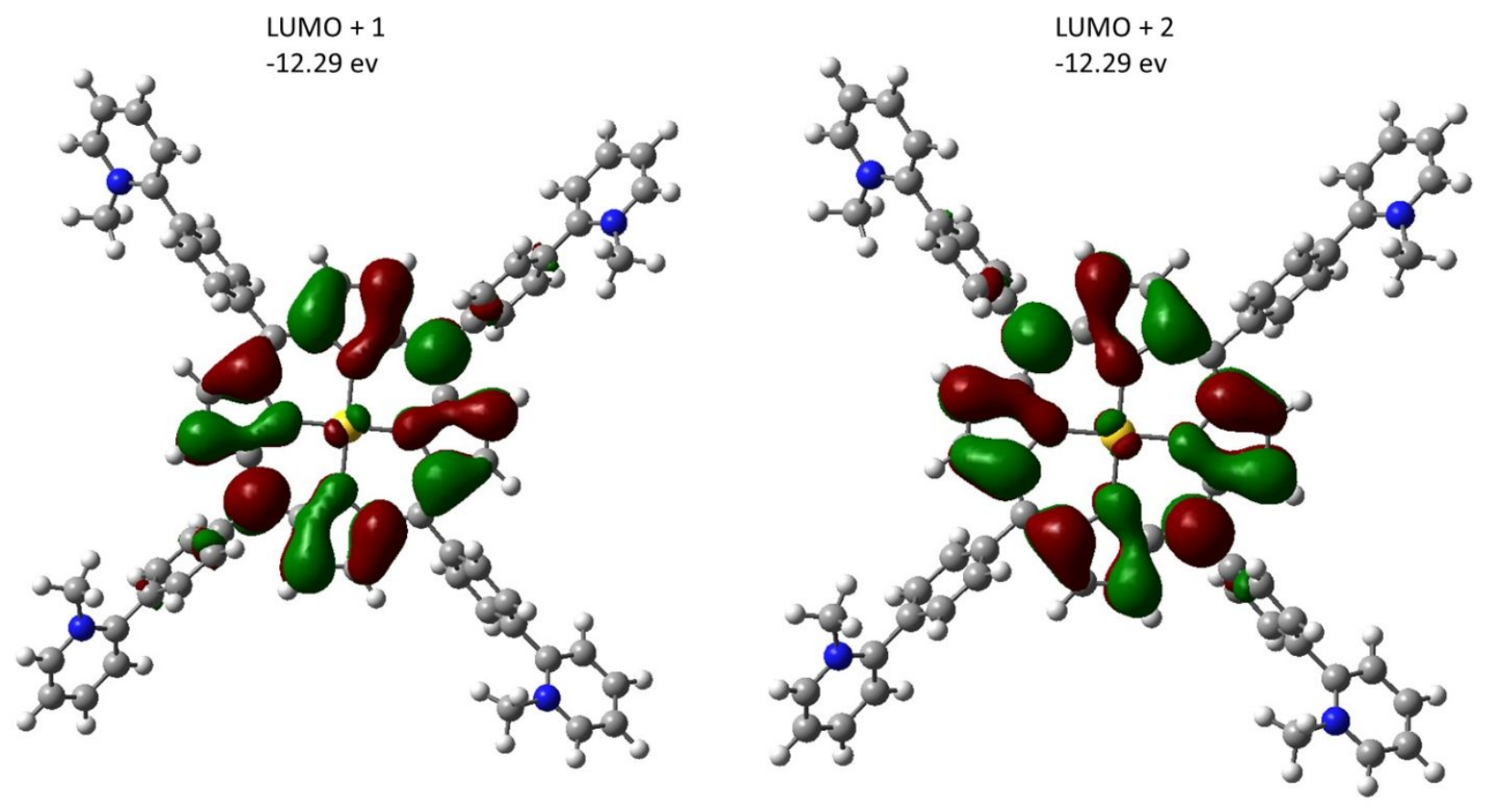

Figure S3. LUMO + 1 and LUMO +2 of AUMA

LUMO + 4

$-9.47 \mathrm{ev}$

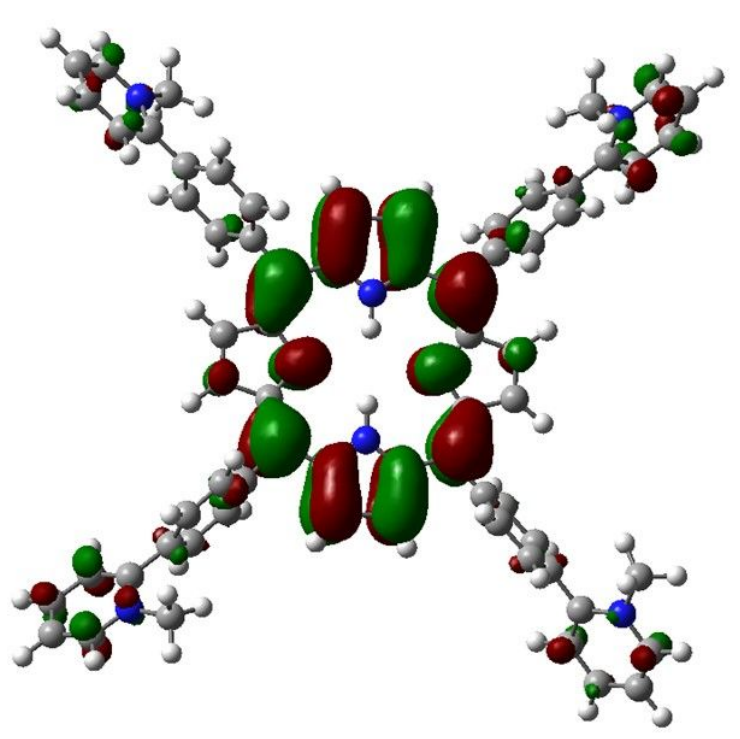

LUMO + 5

$-9.46 \mathrm{ev}$

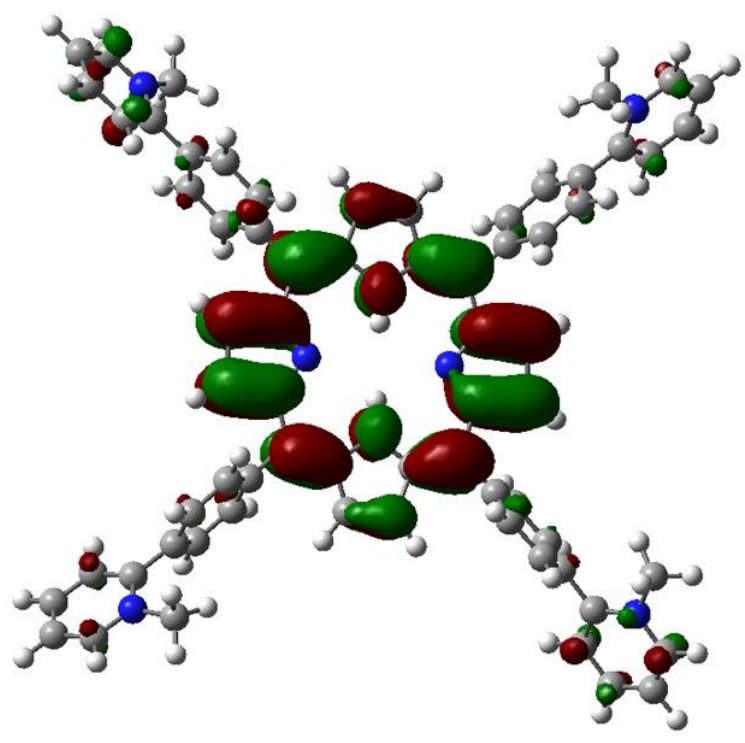

Figure S4. LUMO + 4 and LUMO +5 of H2MA 
Preparation of meso-5,10,15,20-tetrakis(4-( $N$-methyl-pyridinium-2-yl)phenyl)-porphyrinatogold(III) pentachloride (AuMA)

Tetrakis-(4-( $N$-methyl-pyridinium-2-yl)phenyl)porphyrin tetrakis(trifluoroacetate) (89 $\mathrm{mg}, 0.062$ mmole) was dissolved in degassed water $(10 \mathrm{~mL}$ ). Aqueous $0.1 \mathrm{M} \mathrm{NaOH}$ was added ( $248 \mu \mathrm{L}, 0.248$ mmole). Potassium tetrachloroaurate(III) ( $47 \mathrm{mg}, 0.124 \mathrm{mmole}$ ) was dissolved in degassed water (2 $\mathrm{mL}$ ) and added to the porphyrin solution. The mixture was refluxed for 3 hours under argon. The reaction was monitored by UV-visible spectroscopy and was stopped when the Soret band shift was complete (from 437 to $406 \mathrm{~nm}, \mathrm{H}_{2} \mathrm{O}$, acidic $\mathrm{pH}$ ). Desalting of the porphyrin was performed by reverse phase chromatography on a $\mathrm{C} 18$ Sep-Pak cartridge $(5 \mathrm{~g}$, Waters) by elution with Milli-Q water followed by acetonitrile containing $0.1 \%$ trifluoroacetic acid. The collected fractions were evaporated to dryness and the product was taken in methanol/water (50/50). Anion exchange was performed on DOWEX 1x8-200 resin (chloride form, $3 \mathrm{~g}$ ) during 20 hours at room temperature. The solution was filtered off and evaporated to dryness under vacuum. The residue was taken in methanol and precipitated by the addition of diethyl ether, filtered, washed with diethyl ether and dried under vacuum. Yield: $64 \mathrm{mg}(0.047 \mathrm{mmole}, 76 \%)$ vermilion solid. TLC $\mathrm{Rf} \mathrm{CH}_{3} \mathrm{CN} / \mathrm{H}_{2} \mathrm{O} / \mathrm{KNO}_{3}$ sat (6/1/1) 0.24 . UV-visible $\left(\mathrm{H}_{2} \mathrm{O}\right) \lambda=406 \mathrm{~nm} \varepsilon=40010^{3} \mathrm{M}^{-1} \mathrm{~cm}^{-1}$ and $\lambda=521 \mathrm{~nm} \varepsilon=2010^{3} \mathrm{M}^{-1} \mathrm{~cm}^{-1}$. HRMS (+ESI): calcd for $\left[\mathrm{C}_{68} \mathrm{H}_{52} \mathrm{AuN}_{8}\right]^{5+}: 235.4796$, found: $235.4795 .{ }^{1} \mathrm{H}$ NMR $(400 \mathrm{MHz}, \mathrm{MeOD}) \delta_{\mathrm{H}}(\mathrm{ppm})=9.61(\mathrm{~s}$, $8 \mathrm{H}$, pyrrole), $9.26\left(\mathrm{~d}, 4 \mathrm{H}, J_{\mathrm{HH}}=6 \mathrm{~Hz}, \mathrm{pyr}\right), 8.86\left(\mathrm{dd}, 4 \mathrm{H}, J_{\mathrm{HH}}=8\right.$ and $\left.9 \mathrm{~Hz}, \mathrm{pyr}\right), 8.67\left(\mathrm{~d}, 8 \mathrm{H}, J_{\mathrm{HH}}=8 \mathrm{~Hz}\right.$, phe), $8.51\left(\mathrm{~d}, 4 \mathrm{H}, \mathrm{J}_{\mathrm{HH}}=8 \mathrm{~Hz}, \mathrm{pyr}\right), 8.31-8.21\left(\mathrm{~m}, 12 \mathrm{H}\right.$, phe+pyr), $4.66\left(\mathrm{~s}, 12 \mathrm{H}, \mathrm{CH}_{3}\right)$.

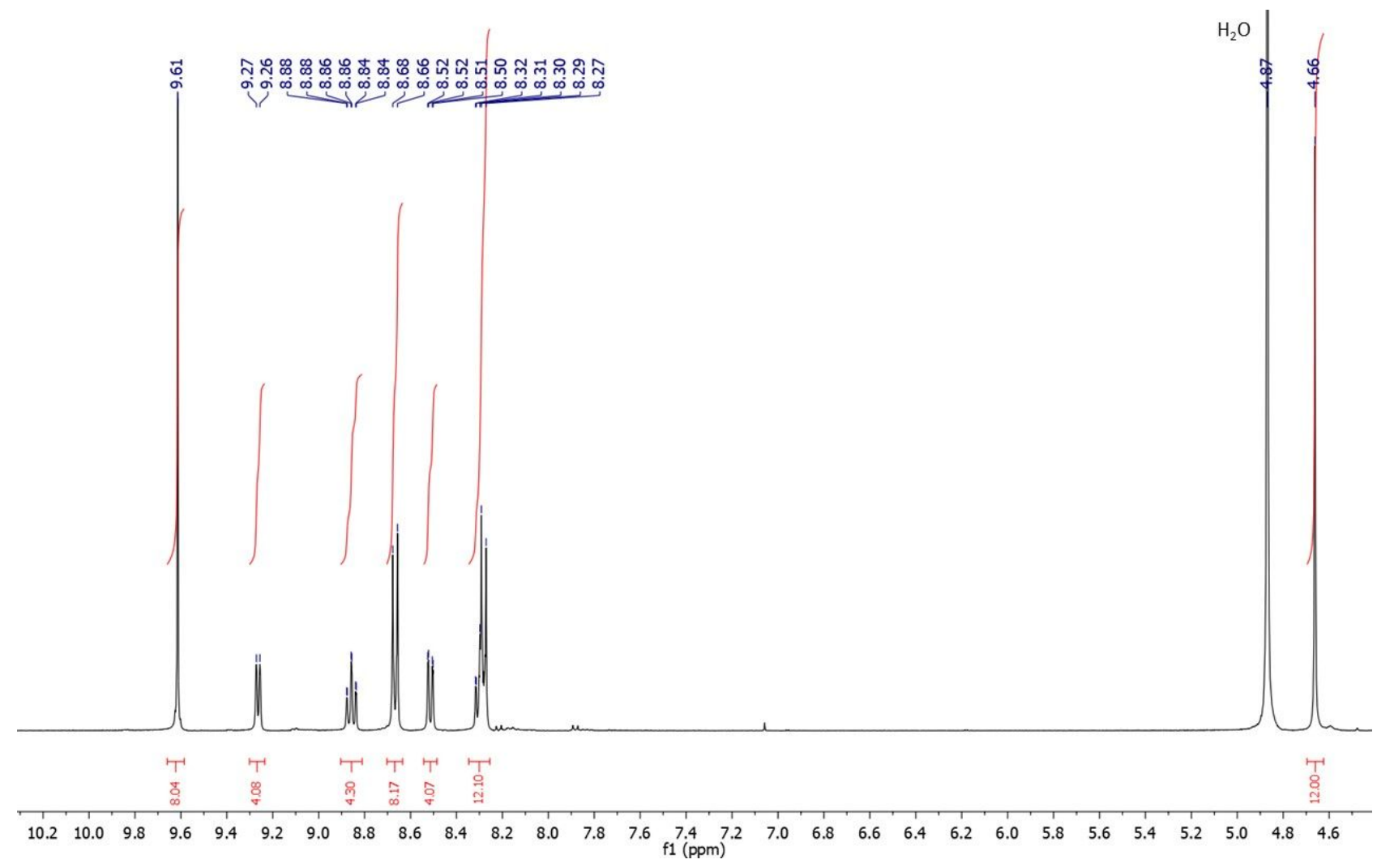

Figure S5. ${ }^{1} \mathrm{H}-\mathrm{NMR}$ spectrum of AuMA (400 MHz, MeOD). 

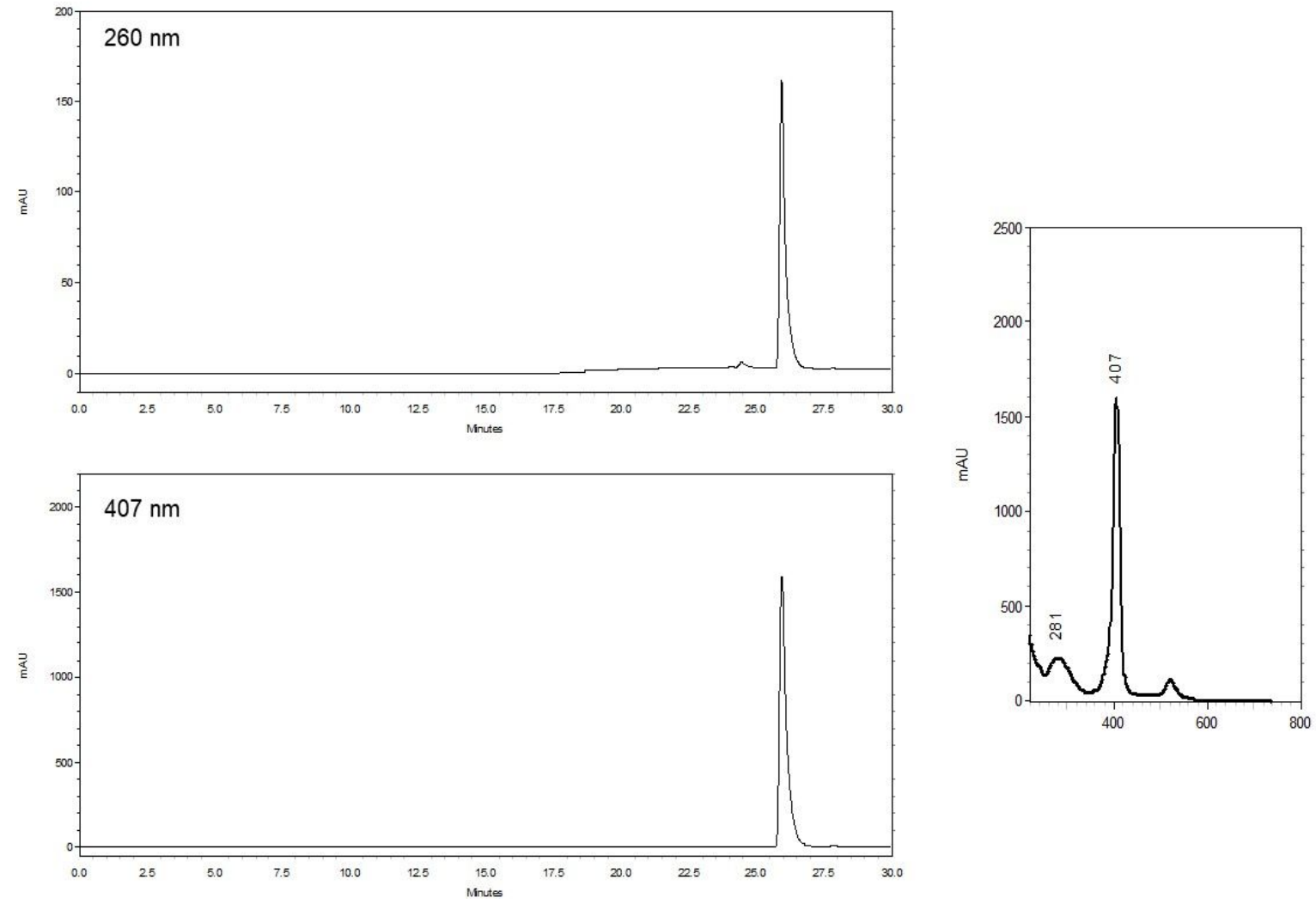

Figure S6. HPLC trace of AuMA with detection at $260 \mathrm{~nm}$ (upper trace) and at $407 \mathrm{~nm}$ (Soret band) (lower trace). The analysis was done on a nucleosil reverse phase C18 $10 \mu$ column eluted with a gradient of water $+0.1 \%$ trifluoroacetic acid and acetonitrile $+0.1 \%$ trifluoroacetic acid, at a flow rate of $0.5 \mathrm{~mL} / \mathrm{min}$. After $5 \mathrm{~min}$ at $100 \%$ water, the percentage of acetonitrile increased to $90 \%$ in $25 \mathrm{~min}$ and it remained at $90 \%$ for $5 \mathrm{~min}$ before returning to the initial conditions. A diode array detector recorded the in-line UV-visible spectrum of AuMA at $26 \mathrm{~min}$ (spectrum: from 200 to $800 \mathrm{~nm}$ ). 